\title{
Shea Tree State of Settlement According to the Cropping Systems in Burkina Faso [Rural Commune of Komki-Ipala (Tampoussoumdi)]
}

\author{
Kadidia Semdé1,2,3*, Hadou Haro¹, Souleymane Ganaba ${ }^{3}$, Irénée Somda ${ }^{2}$ \\ ${ }^{1}$ Microbiology Laboratory, Environment and Forests Department, Environment and Agricultural Research Institute, \\ Ouagadougou, Burkina Faso \\ ${ }^{2}$ University of Nazi Boni, Bobo-Dioulasso, Burkina Faso \\ ${ }^{3}$ Environment and Forests Department, Environment and Agricultural Research Institute, Ouagadougou, Burkina Faso \\ Email: *kadidiasemde@yahoo.fr
}

How to cite this paper: Semdé, K., Haro, H., Ganaba, S. and Somda, I. (2021) Shea Tree State of Settlement According to the Cropping Systems in Burkina Faso [Rural Commune of Komki-Ipala (Tampoussoumdi)]. American Journal of Plant Sciences, 12 , 635-644.

https://doi.org/10.4236/ajps.2021.124043

Received: March 5, 2021

Accepted: April 22, 2021

Published: April 25, 2021

Copyright $\odot 2021$ by author(s) and Scientific Research Publishing Inc. This work is licensed under the Creative Commons Attribution International License (CC BY 4.0).

http://creativecommons.org/licenses/by/4.0/

\section{(c) (i) Open Access}

\begin{abstract}
This study was to assess the effect of bush fires and human actions on the settlement status of the shea tree in cropping systems. It was carried out using three farming systems as treatments in which randomized plots were set. Thus, dendrometric data were collected from the shea trees. The sampling concerned twelve plots of $0.5 \mathrm{ha}(100 \mathrm{~m} \times 50 \mathrm{~m})$ each and the number of adults of shea trees and that of the regeneration per plot was recorded. Forty-five (45) species divided into 20 families and 36 genera have been identified, with a decreasing number ranging from unburned fallow to fields through burnt fallow. From these results, it emerges that the young shea plants are predominant in the unburned fallow. The mapping using geographic coordinates showed that the shea tree gradually aggregated in the fallows with a higher density. Actions must then be taken to support farmers in the domestication and protection of the shea tree for its effective conservation in cropping systems.
\end{abstract}

\section{Keywords}

Agrosystem, Burkina Faso, Dynamics, Shea's Tree

\section{Introduction}

The shea tree (Vitellaria paradoxa), belonging to the Sapotaceae family is also known as Butyrospermum parkii (G. Don) Kotschy. It has been widely used for many purposes of which the most important applications are food and cosmetics [1]. All parts of the tree (root, bark, leaf, nuts, etc.) are used for medicinal pur- 
poses along with remarkable socio-economic importance [2] [3].

However, in Burkina Faso, the landscape is dominated by Shea parks which owe their existence and structure to human intervention [4]. These actions combined with the effects of drought and the environments are factors threatening the species of survival. Indeed, $V$. paradoxa is one of the species that suffer from the negative effects of tillage for farmland development [5], considerably reducing its natural regeneration rate. This does not ensure the sustainability of this species. Thus, woody parks including those of shea trees are experiencing profound evolution between disappearance, degradation, extension or rarely regeneration [6]. The fruit production and the growth of shea trees are affected as a result of a decreased plant density. In fact, in 1946 (Chevalier), the Shea tree density was estimated at 230 trees per hectare. Currently, it was estimated at national level to 30 plants/hectare [7].

Thus, it is essential to develop methods to improve the shea park management. Therefore, this study was initiated to evaluate the shea tree state of settlement according to the cropping systems in Burkina Faso [rural commune of Komki-Ipala (Tampoussoumdi)].

\section{Material and Methods}

\subsection{Study Site}

This study was conducted in the conservation area of Tampoussoumdi village $\left(12^{\circ} 11^{\prime} 36^{\prime \prime}\right.$ North $1^{\circ} 41^{\prime} 13.9^{\prime \prime}$ West) which is located in the rural municipality of Komki Ipala. The latter is part of Kadiogo province $\left(12^{\circ} 20^{\prime} 00^{\prime \prime}\right.$ North, $1^{\circ} 30^{\prime} 00^{\prime \prime}$ West) in the Central region of Burkina Faso, belonging to the Sudano-Sahelian zone. With a surface area of $205.5 \mathrm{~km}^{2}$, the city is at $40 \mathrm{~km}$ far away from Ouagadougou in Ouagadougou-Bobo-Dioulasso axes and covers 18 villages. According to the general population and housing census [8], the population of Tampoussoumdi was estimated to 598 inhabitants and composed of 119 households with 281 men and 317 women. The main activity of the said town is agriculture. The main ethnic groups were Mossis, Gourounsis, Gourmantchés, Samos, Bissa... They were mainly catholics, muslims, protestants and animists [9]. The climate is tropical with two seasons which are the rainy season from June to September characterized by the wet monsoon winds and the dry season from October to May, dominated by Harmattan winds with an average temperature of $29^{\circ} \mathrm{C}$ (Figure 1). During the dry season, it is also observed an average temperature ranging from $17^{\circ} \mathrm{C}$ and $42^{\circ} \mathrm{C}$ between December and February. Average annual rainfall is between 600 and $900 \mathrm{~mm}$ (Figure 2).

The land is relatively flat with small, non-armored, non-rocky elevations. Soils are generally shallow and not very fertile of the tropical ferruginous type, suitable for the farming of cereals [11]. The study site is a shrub savannah characterized by woody species of which the most frequent were from the genus as Lannea, Vitellaria, Combretum etc. This site, which is an agro-pastoral farm (fallow) has an appropriate fencing which provides its protection and promotes the 


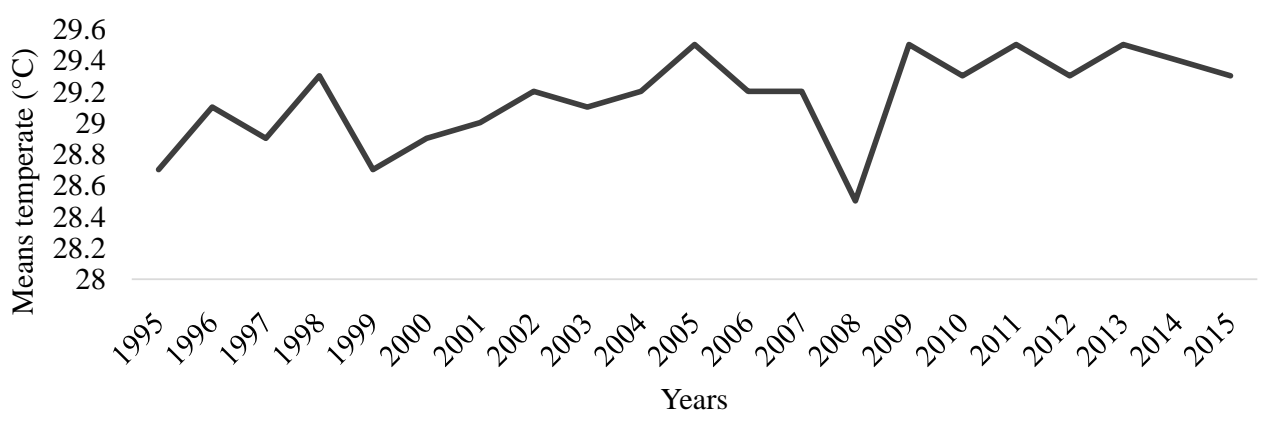

Figure 1. Temperature variation in the central region (Ouagadougou) [10].

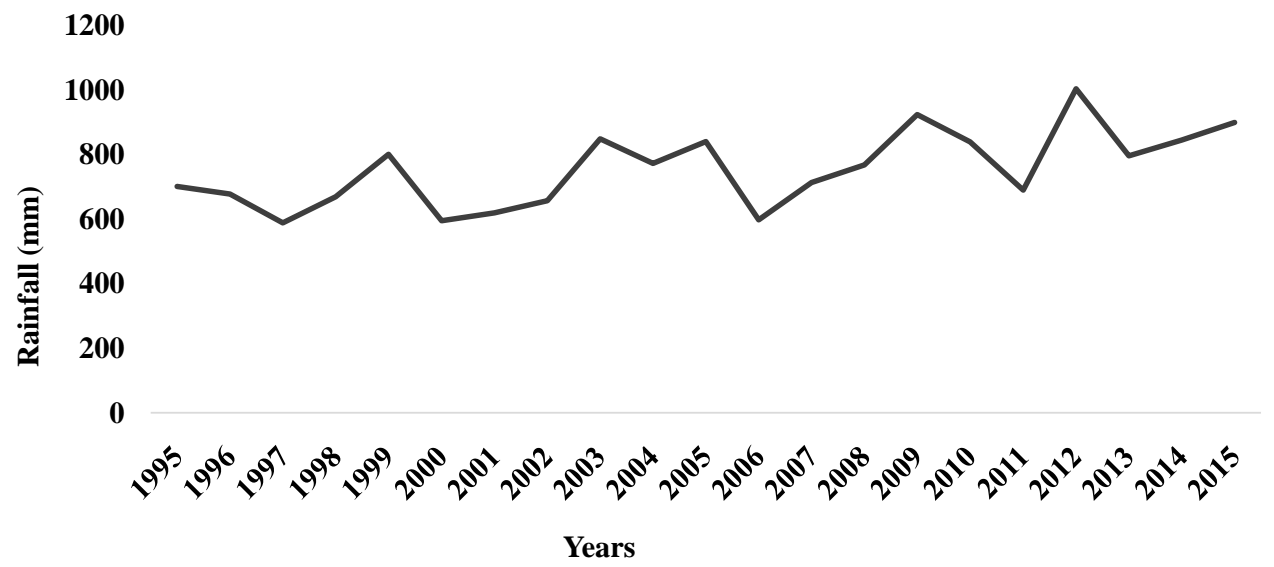

Figure 2. Variation of rainfall in the central region (Ouagadougou) [10].

development of abundant vegetation. The farm delimitation has been made since 2010 and the entire fence is made of barbed wire protection since 2011. Despite this protection, some disturbances in the park are observed and caused by accidental bush fires concerning some part of the fallow. These fires caused extensive damage to the shea trees and shrubs. In general, the vegetation on the site is exposed to a constant degradation due to multiple human pressures, progressively by extension of farmlands, fodder and wood cutting by the surrounding populations and the growing urbanization.

\subsection{Floristic Inventory}

An inventory was carried out in unburned fallow, burned fallow and in the agricultural fields. A sampling device used is a one-factor plan which considers cropping systems (fallow, agricultural fields). It consisted of three plots ( $\mathrm{PC}=$ field, $\mathrm{JNB}=$ unburned fallow, JB = burned fallow), with an area of two hectares ( $2 \mathrm{ha}$ ) per plot. Inside, each plot was placed 4 rectangular plots $(100 \mathrm{~m} \times 50 \mathrm{~m})$ [12], and according to Thiombiano et al. [13], the minimum area is estimated at 2500 $\mathrm{m}^{2}$. The lengths and widths of the plots were measured using two metric tapes to $50 \mathrm{~m}$ in length metric tapes. Thus, for a better precision of the limits, the GPS coordinates were recorded at the level of the corner of each plot. This device is composed of twelve (12) plots (6 ha) randomized on which the dendrometric data were collected. 


\subsection{Data Collection and Processing}

Data collection consisted of identifying and mapping all individuals of the shea trees present in all the plots and measuring the dendrometric parameters. These parameters were the plant height (estimated visually), the diameter (recording at a height of $1.30 \mathrm{~m}$ above the ground). State of regeneration of shea was assessed by counting all the juvenile individuals (plants with a diameter less than or equal to $5 \mathrm{~cm}$ and height less than $1.30 \mathrm{~m}$ ). Geographic coordinates were used to analyze the spatial distribution of the shea trees species model [14]. Density $(N)$ is the average number of standing individuals estimated per hectare was calculated according to the formula (for the Shea tree): $N=\frac{n}{s} ; n$ : number of individuals and $s$ the area covered (ha).

\subsection{Statistical Analyzes}

Data were statistically analysis with the statistical software XLSTAT 2019. When the variable from which the sample is drawn follows a normal distribution and the samples variances are homogeneous, the data are analyzed using a one-way analysis of variance (ANOVA) and the variables means were compared using the Newman Keuls test $(\mathrm{p}<5 \%)$. All other data were analyzed using a Kruskal-Wallis test and row means were compared using the Conover-Iman test $(\mathrm{p}<5 \%)$.

\section{Results}

\subsection{Structure}

Statistical analysis on dendrometric parameters showed that the average plant height varied among the studied farming systems (Figure 3 ). The lowest values of the plant height were observed for JNB.

Considering the diameter of $V$. paradoxa, results indicated a predominance of individuals with a small diameter $([1-5[\mathrm{~cm})$ in JNB farming systems (76 individuals) while individuals with large diameter $([25-50[\mathrm{~cm})$ were found in the PC farming system (Figure 4).

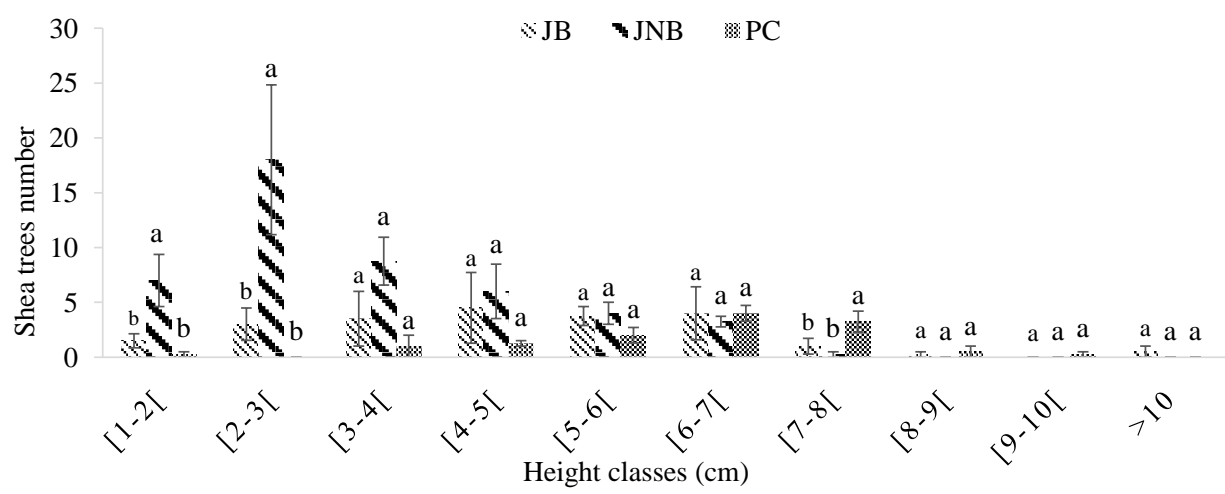

Figure 3. V. paradoxa vertical structure based on height classes. PC: field, JNB: unburnt fallow, JB: burnt fallow. For each cropping systems, data followed by the same letters are not significantly different according to the Newman-Keuls test ( $p>0.05)$. 


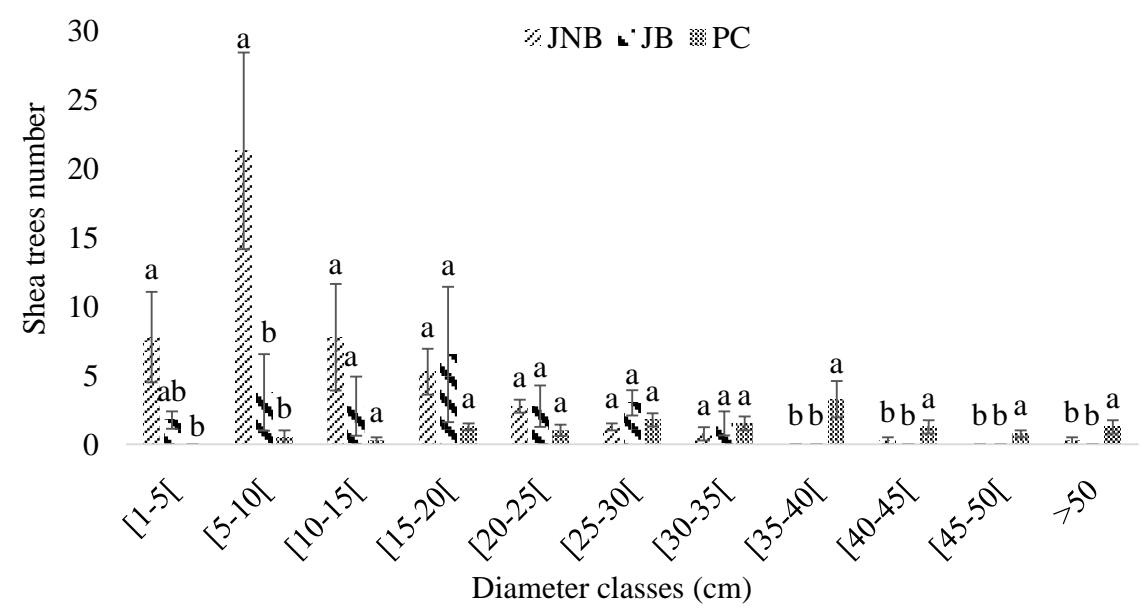

Figure 4. V. paradoxa horizontal structure based on height classes. PC: field, JNB: unburnt fallow, JB: burnt fallow. For each cropping systems, data followed by the same letters are not significantly different according to the Newman-Keuls test $(\mathrm{p}>0.05)$.

Figure 5 shows a spatial distribution of the shea in fallows ( $a$ and $b$ ) and in the agricultural field (c).

\subsection{Shea Stands Density and Regeneration}

Table 1 shows the shea tree density and regeneration. The average density was found to be high in JNB (199 plants/ha). With regards to the number of juvenile plants recorded, it varied from farming system to another. Conover-Iman test showed a significant difference for natural regeneration and density between the fallows and fields $(\mathrm{P}<0.05)$. The lower values of regeneration rate $(3 \%)$ were obtained in agricultural fields (PC).

\section{Discussion}

$V$. paradoxa dendrometric characteristics statistical analyzes showed that the most vigorous individuals in terms of diameter and height found in the PC. These results are linked to the aging of the aging of the trees. These results are linked to the aging of the trees. However, previous studies showed that this diameter and height growth are attributed to the maintenance provided by farmers to shea trees during agricultural works [15] [16] and anthropophilic preferences for the species. But the low proportions of individuals of small diameters observed in the fallows are explained by their adaptation to their ecological environment and the competition for light and space. [17] [18]. This also corroborates the results of [19] [20], who showed that shea is a species frequently encountered in association with other woody species such as Detarium microcarpum, Piliostigma tonningii, Lannea microcarpa etc., but who likes light, open and aerated areas. As shown in the histograms, it was confirmed that young individuals of $V$. paradoxa were abundant in JNB, compared to that of fields. Indeed, more than $75 \%$ of shea trees were found in the diameter classes [1 $10[\mathrm{~cm}$, thus reflecting its good regeneration. These results are in agreement with 

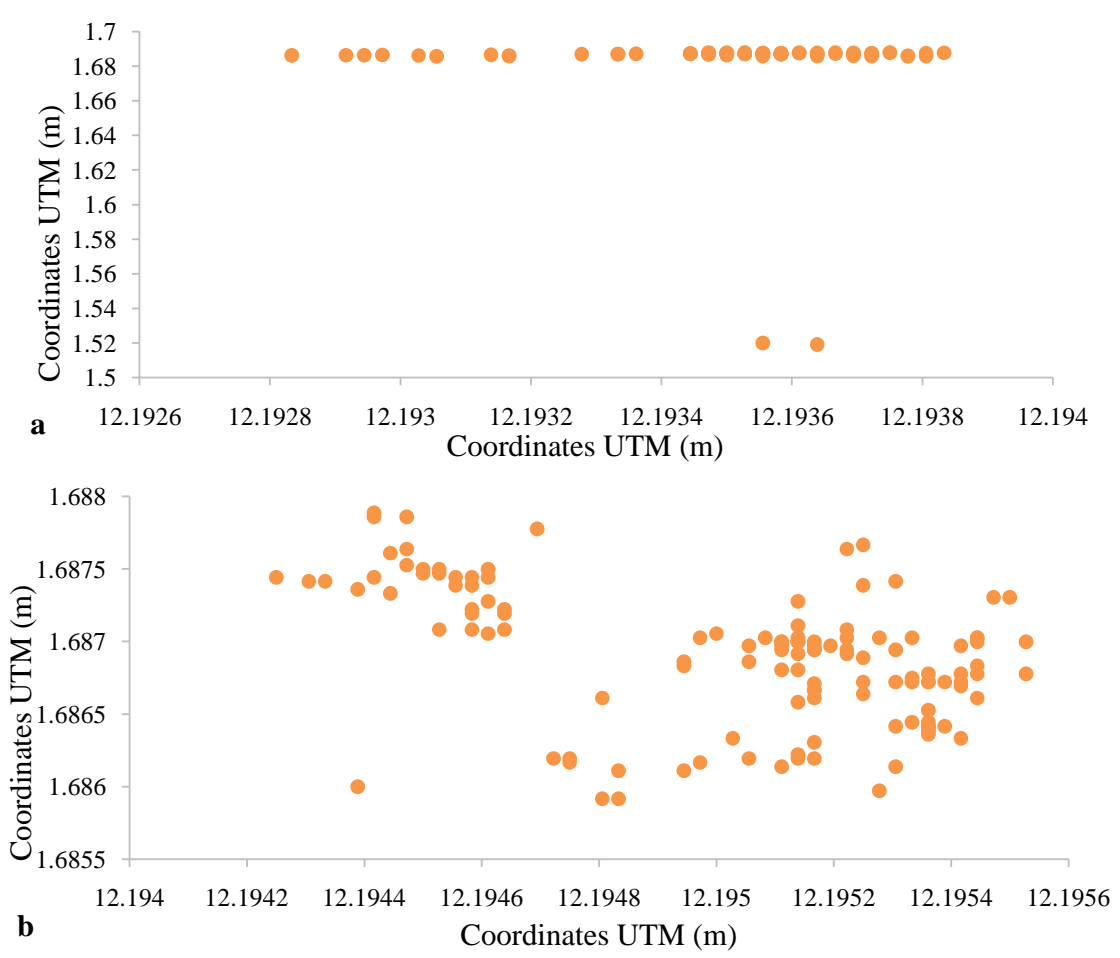

Figure 5. Shea individuals distribution in burnt fallow (a), unburned fallow (b) and in the field (c).

Table 1. Means of shea stands according to cropping systems.

\begin{tabular}{cccc}
\hline Treatments & Adult individuals & Natural regeneration & Density (shea trees number/ha) \\
\hline JNB & $47.25 \pm 25.55^{\mathrm{a}}$ & $51.75 \pm 35.96^{\mathrm{a}}$ & $199 \pm 106.20^{\mathrm{a}}$ \\
JB & $22 \pm 24.04^{\mathrm{a}}$ & $36.5 \pm 31.25^{\mathrm{a}}$ & $117 \pm 109^{\mathrm{ab}}$ \\
PC & $12.50 \pm 4.80^{\mathrm{a}}$ & $4.5 \pm 2.4^{\mathrm{b}}$ & $34 \pm 11.70^{\mathrm{b}}$ \\
Significance level & NS & $\mathrm{P}=0.015$ & $\mathrm{P}=0.024$ \\
\hline
\end{tabular}

NS: No significant; PC: field, JNB: unburnt fallow, JB: burnt fallow; For each cropping systems, data followed by the same letters are not significantly different according to the Conover-Iman test ( $p>0.05)$.

those of Palmerg (1985) reported by Diarrassouba et al. [21] and of Gnonlonfoun et al. [22], which showed that finding a plant with a diameter greater than 5 $\mathrm{cm}$ among forest species indicates a good natural regeneration. However, in this study, the large number of shea tree regeneration could be as a result of the protection which has been provided for the fallows. On the other hand, the observed low numbers of individuals in other classes, particularly in the height class [1 $2[\mathrm{~m}$ [which is an important stage of survival and growth in the plant species replacement process according to [23]], revealed a high mortality of the shea tree in JB and PC. This mortality could be seen as a result of the negative effects of bush fires on vegetation and other human actions on the juvenile plants [24]. Similar results were found by Ouoba et al. [25], highlighting the detrimental effects of bush fires, combined with the reduction in rainfall patterns on plant species and its juveniles particularly. This was also confirmed by the means com- 
parison test $(\mathrm{p}<0.05)$ which indicates significant differences between the studied systems with regards to the shea tree juvenile stratum and justifies the previous results on bush fires, which allow the destruction of young plants. Similar results were found by Kaboré et al. [2] who also pointed out that these fires induce natural abscission during the dry season despite a fairly deep-rooted system of the shea tree. This agrees with Yelemou et al. [26] results on Piliostigma, who highlighting that these fires stand for real threats in the regeneration of woody species.

In contrast, the complete lack or the low replacement rate of adult shea trees in the agricultural fields suggests that there was no regeneration, yet that the few remaining seeds after fruits collection germinate and yield to juvenile plants which do not grow properly in this environment. Thus, the observed low regeneration in the agricultural field could be as a result of an important fruits collection along with the occurrence of agricultural practices (removal of plants because of its slow growth which is not favorable for farmers protection) and the difficulty of young plants to survive during the dry season. Thus, studies of Ouoba et al. [27]; [13] showed that lands clearing for agriculture is one of the factors interacting with the potential for regeneration of plant species leading to a low density, hence the aging of individuals. Further, it was observed that the shea tree density decreased from the fallow to the agricultural fields. This is because fruits collection by farmers was more important in the fields than that in the fallows, leading to this regressive dynamic in the fields. The lack of plant protection also affects the spatial distribution of the species, which remains random in the fields while tending to be aggregated in the fallows [22] [28]. This was supported by Kelly et al. [29] showing that the distribution of plants tends to be more aggregated as the farming systems changed from fields to fallows, explaining the aging of the shea trees. Thus, in order to contribute to the better regeneration of the shea tree, it would be necessary to reduce fruits collection and to prevent bush fires which are important steps for its protection.

\section{Conclusion}

This study revealed that the density of the shea tree is decreasing from the fallows to the field in Komki Ipala. Bush fires, anthropogenic disturbances, and especially fruit collection remain the main factors leading to this decreasing plant density along with the aging of the shea tree. However, the representativeness of the recorded regeneration in the fallows as a result of a certain protection could ensure the shea trees replacement, provided that factors limiting the aging of this species are effectively challenged. Thus, to fight against the aging of shea parks, we suggest that the protection of young plants to reach a less vulnerable stage with a sufficient plant height should be considered through monitoring. More efforts should also be provided in protecting the shea trees by building up good fencing systems for the fallows. This would show the importance of protected fallows in the shea trees restoration and the species conservation. 


\section{Conflicts of Interest}

The authors declare no conflicts of interest regarding the publication of this paper.

\section{References}

[1] Diarrassouba, N. (2008) Morphological characterization in Shea: V. paradoxa C. F. Gaertn (Sapotaceae) and Analysis of Certain Anthropogenic Factors Affecting the Structure of Genetic Diversity of Stands in Côte d'Ivoire. Thesis in Science, Genetics and Plant Breeding, University of Abidjan-Cocody, Côte d'Ivoire, 126 p.

[2] Kaboré, S.A., Bastide, B., Traoré, S. and Boussim, J.I. (2012) Dynamics of Shea, V. paradoxa in the Agrarian Systems of Burkina Faso. Tropical Woods and Forests.

[3] Diarrassouba, N., Yao, S.D.M. and Traoré, B. (2017) Participatory Identification and Characterization of Elite Shea Trees in the Production Area in Côte d'Ivoire. Progress Report No. 2 FIRCA/Shea Project No. 069/2016. 15 p.

[4] Mbayngone, E., Thiombiano, A., Hahn-Hadjali, K. and Guinko, S. (2008) Structure of the Woody Plants of the Pama Reserve (South-East of Burkina Faso, West Africa). Flora et Vegetatio Sudano-Sambesica, 11, 25-34. https://doi.org/10.21248/fvss.11.4

[5] Djossa, B.A., Fahr, J., Wiegand, T., Ayihouenou, B.E., Kalko, E.K. and Sinsin, B.A. (2007) Land Use Impact on V. paradoxa C.F. Gaerten. Stand Structure and Distribution Patterns: A Comparison of Biosphere Reserve of Pendjari in Atacora District in Benin. Agroforestry Systems, 72, 205-220. https://doi.org/10.1007/s10457-007-9097-y

[6] Boffa, J.M. (2014) Regenerating Shea Parklands for Sustained Productivity and Diversity: Strategy Components.

[7] CIR, ITC (2014) National Sustainable Development Strategy for the Burkina Faso Shea Sector, 2015-2019, Workshop Report, Ouagadougou, Burkina Faso. 140 p.

[8] (2008) General Population and Housing Census of 2006. Final Results, Burkina Faso, $52 \mathrm{p}$.

[9] Traoré, I. (2010) Study of the Underground Water Potential of the Komki-Ipala Plain for Water and Irrigation Needs. Mémoiry, 2ie, Burkina Faso, 74 p.

[10] National Meteorological Agency-Burkina Faso (2021) Data Collected by the Weather Forecast from 1995 to 2021

[11] Somda, N.A. (2012) Problem of the Implementation of Communal Development Plans (PCD) over the Period 2009-2011: Case of the Central Region (Burkina Faso). Mémoiry MSO2, $66 \mathrm{p}$.

[12] Agbogan, A., Bammite, K., Wala, K., Bellefontaine, R., Dourma, M., Akpavi, S., Woegan, Y.A., Tozo, K. and Akpagana, K. (2017) Natural Regeneration of a Spontaneous Fruit Tree: Lannea microcarpa Engl. and K. Krause in Northern Togo. African Agronomy, 29, 279-291.

[13] Thiombiano, A., Glele Kakaï, R., Bayen, Boussim, J.I. and Mahamane, A. (2016) Methods and Devices for Forest Inventories in West Africa: Inventory and Proposals for Harmonization. Annals of Agronomic Sciences, 20, 15-31.

[14] Djossa, B.A., Fahr, J., Wiegand, T., Ayihouenou, B.E., Kalko, E.K. and Sinsin, B.A. (2007) Land Use Impact on Vitellaria paradoxa C.F. Gaerten. Stand Structure and Distribution Patterns: A Comparison of Biosphere Reserve of Pendjari in Atacora District in Benin. https://doi.org/10.1007/s10457-007-9097-y 
[15] Djekota, C., Mouga, M., Djimramadji, A., Djelassem, B., Mbayngone, E., Maiga, R.D., Rimgoto, K. and Noubady, D. (2014) Morphological Characterization of Shea tree ( $V$. paradoxa subsp. paradoxa) Populations in the Region of Mandoul in Chad. International Journal of Biodiversity and Conservation, 6, 184-193. https://doi.org/10.5897/IJBC2013.0662

[16] Boffa, J.M. (2015) Opportunities and Challenges in the Improvement of the Shea (Vitellaria paradoxa) Resource and Its Management. Global Shea Alliance, Ghana.

[17] Yelemou, B., Bationo, B.A., Yameogo, G. and Millogo-Rasolodimby, J. (2007) Traditional Management and Uses of Piliostigma reticulatum on the Central Plateau of Burkina Faso. Tropical Woods and Forests, 291, 55-66.

[18] Ouédraogo, O., Thiombiano, A., Hahn-Hadjali, K. and Guinko, S. (2009) Diversity and Dynamics of the Juvenile Woody Vegetation of the Arly National Park (Burkina Faso). Candollea, 64, 257-278.

[19] Hans-Jürgen, V.M. (1992) Trees and Shrubs of Sahel. Their Characteristics and Uses. $531 \mathrm{p}$.

[20] Diarrassouba, N., Koffi, K.E., N’Guessan, K.A., Damme, V.P. and Sangare, A. (2008) Local Knowledge and Its Use in the Management of Shea Parks in Côte d'Ivoire. Afrika Focus, 21, 77-96. https://doi.org/10.1163/2031356X-02101007

[21] Diarrassouba, N., Fofana, J.I., Bakayoko, A., Nguessan, A.K. and Angare, A. (2009) Influence of Agrarian Systems on the Dynamics of Natural Regeneration of Shea: $V$. paradoxa CF Gaernt (Sapotaceae) in Côte d'Ivoire. African Agronomy, 21, 49-58. https://doi.org/10.4314/aga.v21i1.46204

[22] Gnonlonfoun, R., Glèlè, Kakaï, V.K., Salako, A.E., Assogbadjo, A.E. and Ouédraogo, A. (2015) Structural Analysis of Regeneration in Tropical Dense Forest: Combined Effect of Plot and Spatial Distribution Patterns. Acta Botanica Gallica: Botany Letters, 162, 89-96. https://doi.org/10.1080/12538078.2014.984332

[23] Ouédraogo, A. (2006) Diversity and Dynamics of the Woody Vegetation of the Eastern Part of Burkina Faso. Single Doctoral Thesis, University of Ouagadougou, Ouagadougou, $195 \mathrm{p}$.

[24] Vieira, D.L.M. and Scariot, A. (2006) Principles of Natural Regeneration of Tropical Dry Forests for Restoration. Restoration Ecology, 14, 11-20. https://doi.org/10.1111/j.1526-100X.2006.00100.x

[25] Ouoba, H.Y., Bastide, B., Coulibaly-Lingani, P., Kabore, S.A. and Boussim, J.B. (2018) Knowledge and Perceptions of Producers on the Management of Shea Tree Parks in Burkina Faso. International Journal of Biological and Chemical Sciences, 12, 2766 2783. https://doi.org/10.4314/ijbcs.v12i6.23

[26] Yelemou, B., Yameogo, G., Bationo, B.A., Millogo, R.J. and Hien, V. (2012) State of Stands, Dynamics of Sexual Regeneration and Anthropogenic Pressure. International Journal of Biological and Chemical Sciences, 6, 2083-2096. https://doi.org/10.4314/ijbcs.v6i5.17

[27] Baggnian, I., Adam, T., Adamou, M.M., Chaibou, I. and Mahamane, A. (2014) Structure and Dynamics of Juvenile Woody Vegetation Resulting from Assisted Natural Regeneration (ANR) in the Center-Sud of Niger. International Journal of Biological and Chemical Sciences, 8, 649-665. https://doi.org/10.4314/ijbcs.v8i2.22

[28] Rabiou, A., Diouf, A., Bationo, B.A., Mahamane, A., Segla, K.N., Adjonou, K., Radji, R., Kokutse, R.D., Kokou, K. and Saadou (2015) Seedlings of Pterocarpus erinaceus Poir in the Tiogo Forest in the Sudanian Zone of Burkina Faso. International Journal of Biological and Chemical Sciences, 9, 69-81.

https://doi.org/10.4314/ijbcs.v9i1.7 
[29] Kelly, B. (2005) Impact of Human Practices on Population Dynamics and on the Genetic Diversity of Shea in Agroforestry Systems in Southern Mali. Doctoral Thesis of the University from Bamako, Mali, 233 p. 